(C) 2001 The Chemical Society of Japan

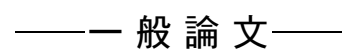

\title{
エーテル系ウレタンプレポリマーおよび ポリウレタンェラストマーの水素結合性
}

(2001 年 1 月 18 日受理)

松永勝治*·近江＼cjkstart誠

\begin{abstract}
ジイソシアナートとして 4,4'-メチレンビス(フェニル)ジイソシアナート，エーテル系ポリオールと して $\alpha$-ヒドロ- $\omega$-ヒドロキシポリ (オキシプロピレン) (PPG) および $\alpha$-ヒドロ- $\omega$-ヒドロキシポリ (オキ シテトラメチレン) (PTMG)を用いたウレタンプレポリマー(ITUP) 抢よびポリウレタンエラストマー (PUE)のキャラクタリゼーションを示差走查熱量測定 (DSC)抢よび FTIRにより行った．DSC から求 めた ITUP および PUE のガラス転移温度 $\left(T_{\mathrm{g}}\right)$ は用いたエーテル系ポリオールの $M_{\mathrm{n}}$ とともに低下する が，両者の $T_{\mathrm{g}}$ 值に有意差は認められない. ITUP およびPUE の $T_{\mathrm{g}}$ 值をポリオール単独のそれと比べ ると，PTMG 系よりも PPG 系の方が大幅に上昇する．ITUP および PUE 中の水素結合による物理的 橋かけがソフトセグメントとハードセグメントとの間抢よびハードセグメントとハードセグメントとの 間に形成され，後者の方が橋かけ密度は高い. PPG 系の $\mathrm{NH}_{\mathrm{C}-\mathrm{O}-\mathrm{C}}(\%)$ は PTMG 系のそれよりも高く, 逆に PPG 系の $\mathrm{NH}_{\mathrm{C}=0}(\%)$ は $\mathrm{PTMG}$ 系のそれよりも低いことから，PTMG 系の方が強固なハードド メインが形成される.
\end{abstract}

\section{1 はじめに}

ポリウレタンエラストマーの製造では，分子の対称性がよいジ イソシアナートとして 4,4'-メチレンビス(フェニル)ジイソシア ナート (MDI)が多用されており，またエーテル系ポリオールと して $\alpha$-ヒドロ- $\omega$-ヒドロキシポリ（オキシプロピレン）(PPG)お お

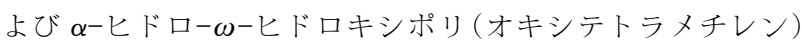
(PTMG) が広く用いられている.PPG とPTMGの化学構造の 相違は生成ポリウレタンの種々の物理的性質に顕著な变動をもた らし，それを詳細に調べることは，これらポリオールを用いる機 能性ポリウレタン創製の分子設計には必要不可欠である.

ポリウレタンはソフトセグメントとハードセグメントから構成 される二層構造ポリマーであり，この相分離構造は物理的性質に 顕著な影響を及ぼす。すなわち，ポリオールに由来するソフトセ グメントは高伸長, 弾性回復に貢献し, ジインシアナートや鎖延 長剂を典拠とするハードセグメントは高モジュラス，高強度に寄 与する. 相分離構造は相の溶解度パラメーター, 結晶性, 温度およ び熱履歴に依存し，その詳細が示差走査熱量測定 $(\mathrm{DSC})^{1)-6)}$, 透 過型電子顕微鏡 ${ }^{7)}$, 動的粘弾性 ${ }^{8)-10)}$, 誘電測定 ${ }^{11)}$, FTIR $^{12)-17)}$ 打 よび NMR ${ }^{18)-20)}$ などにより精査されている.

著者ら ${ }^{21)}$ はさきに, MDI 2 mol と PPG 1 mol または PTMG 1 $\mathrm{mol}$ を用いたウレタンプレポリマー(ITUP)のサイズ排除クロマ

東洋大学工学部応用化学科, 350-8585 川越市鯨井 2100

†現在 旭電化工業株式会社機能性樹脂開発研究所, 346-

0101 埼玉県南埼玉郡菖蒲町昭和沼 20
トグラフィー, DSC, 粘度法抢よび FTIR によるキャラクタリ ゼーションを行った．その結果は以下の 2 点に要約される.

(1) ITUP は単なるイソシアナート両末端の三量体(式 (1)に 拈いて $n=0)$ ばかりでなく，イソシアナート両末端の多量体(式 (1)に扎いて $n=1,2,3 \cdots)$ を含んでおり，その生成の動力学 は段階的生長重合の統計論に従う.

（2） ITUP のガラス転移温度，粘性挙動および C-O-C 伸縮振 動の温度依存性に及ぼすポリオールの構造の影響が顕著に具現さ れる.

今回は，上記の ITUP ばかりでなく, MDI と PPG または PTMG との等モル反応からのポリウレタンエラストマー(PUE) のガラス転移温度および水素結合性をそれぞれDSC および FTIR により調べ，有用な知見が得られたので報告する。

\section{2 実験}

\section{1 試薬}

PPG (三井東圧化学製) および PTMG (保土ヶ谷化学製) は, $100{ }^{\circ} \mathrm{C} / 1.33 \mathrm{kPa}$, 窒素気流下で 8 時間乾燥させたものを使用し た．MDI (日本ポリウレタン工業製) は純度 $99.8 \%$ ものをその まま用いた。

\subsection{ITUP および PUE の合成}

ITUPの合成(式 (1)，ポリオールに対するMDIのモル比は 2.0)は既報 ${ }^{21)}$ と同様に行った. ITUPは，式( 1 )における $n$ の值 が $0,1,2$ ，のときに，それぞれ 3 量体，5量体， 7 量体になり， これ以上の重付加体も含めたプレポリマーの混合物である. 
$\mathrm{HO}-\mathrm{P}-\mathrm{OH}+2 \mathrm{OCN}-\mathrm{R}-\mathrm{NCO} \rightarrow$

polyol diisocyanate

$\mathrm{OCN}-\mathrm{R}-\mathrm{NHCO}[\mathrm{O}-\mathrm{P}-\mathrm{OCONH}-\mathrm{R}-\mathrm{NHCO}]_{n} \mathrm{O}-\mathrm{P}-$

OCONH-R-NCO

isocyanate-terminated urethane prepolymer(ITUP)

P: oxypropylene or oxytetraethylene units, R: 4,4'methylenebis (phenyl)

$n=0,1,2, \cdots$

PUEの合成(式 (2))は以下のように行った．ポリオールに対 する MDI のモル比を 1.0 とし, 触媒としてジブチルすずジラウ

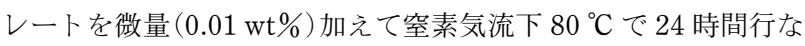
い, $120{ }^{\circ} \mathrm{C}$ で 2 時間ポストキュア (後硬化)してPUEを得た. ${ }^{1} \mathrm{H}$ -NMR によりウレア結合の不在を確認して分析試料とした.

\section{$\mathrm{HO}-\mathrm{P}-\mathrm{OH}+\mathrm{OCN}-\mathrm{R}-\mathrm{NCO} \rightarrow$}

$[-\mathrm{O}-\mathrm{P}-\mathrm{OCONH}-\mathrm{R}-\mathrm{NHCO}-]_{n}$

linear polyurethane elastomer(PUE)

式 (1) および式 (2) における $\mathrm{P}$ の部分がソフトセグメント で，その他の部分はハードセグメントである.

\section{3 キャラクタリゼーション}

2.3.1 ガラス転移温度の測定：DSC (セイコー電子工業製 SSC220 型)により, アルミニウム製セルを用いて, 窒素雾囲気 中, 昇温速度 $5{ }^{\circ} \mathrm{C} / \mathrm{min}$ で測定した.

2.3.2 FTIR スペクトルの測定 : ITUP およびPUE のクロロ

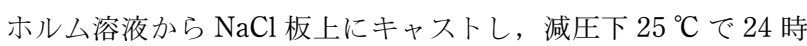
間乾燥して試料とした. FTIR (日本電子製, JIR-7000 型) スペ
クトルを室温で測定したのち，データ解析ソフト“DECONVOLUTION”プログラムにより波形分離した.

\section{3 結果および考察}

\subsection{DSC}

PPG 系 PUE, PTMG 系 ITUP および PUE の DSC 曲線を Fig. 1 に示す. Fig. 1 から得られたソフトセグメントのガラス転 移温度 $\left(T_{\mathrm{g}}\right)$ を Table 1 に示す. Table 1 には PPG 単独および PTMG 単独の $T_{\mathrm{g}}$ 值も併記した. Table 1 から ITUP および PUE の $T_{\mathrm{g}}$ 值はともに PPG 単独および $\mathrm{PTMG}$ 単独の $T_{\mathrm{g}}$ 值より もかなり高い值であることがわかる．このことは，ハードセグメ ントがソフトセグメントのミクロブラウン運動に対する顕著な抑 制効果を持っている証拠である.すなわち，オキシプロピレン鎖 またはオキシテトラメチレン鎖のミクロブラウン運動が, これら の鎖の両端部分の水素結合性ウレタン結合を含有するハードセグ メントによって阻害されることを示唆している. PPG 単独およ び PTMG 単独の $T_{\mathrm{g}}$ 值は $M_{\mathrm{n}}$ に依存せずほぼ一定である. 一方, ITUP およびPUE の $T_{\mathrm{g}}$ 值はポリオールの $M_{\mathrm{n}}$ が高くなるにつ れて，すなわちソフトセグメント濃度 (SSC, Table 1)が高くなる につれて低下する.PPG系㧍よび PTMG 系とも ITUP と PUE の $T_{\mathrm{g}}$ 值に顕著な相違は認められない.

一般に, コポリマーの $T_{\mathrm{g}}$ は次の式 22 に従うことが知られてい る.

$$
\frac{1}{T_{\mathrm{g}}}=\frac{w_{1}}{T_{\mathrm{g}_{1}}}+\frac{w_{2}}{T_{\mathrm{g}_{2}}}
$$

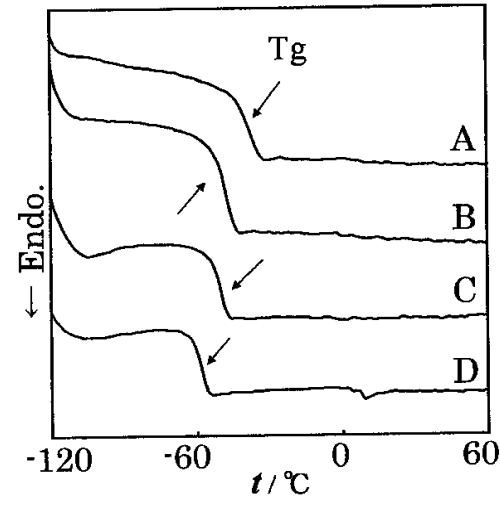

(a) :PPG-based PUE

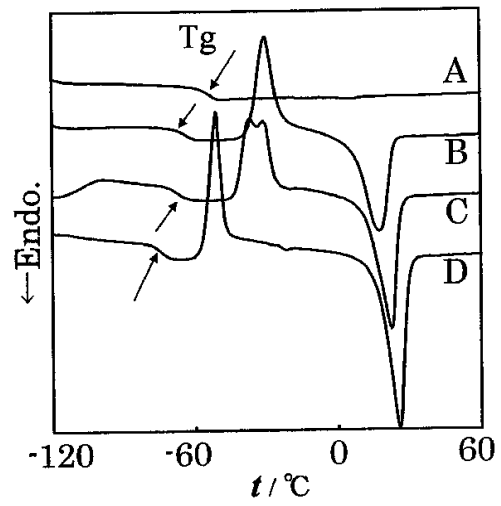

(b) :PTMG-based ITUP

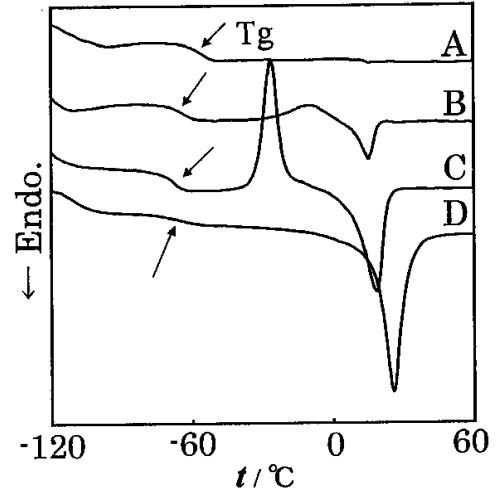

(c) :PTMG-based PUE

Fig. 1 DSC curves of urethane prepolymer (ITUP) and Polyurethane elastomer (PUE). $M_{\mathrm{n}}$ of polyol=1000(A), $1500(\mathrm{~B}), 2000(\mathrm{C}), 3000(\mathrm{D})$.

Table $1 T_{\mathrm{g}}$ value of polyols, ITUPs and PUEs

\begin{tabular}{|c|c|c|c|c|c|c|c|c|}
\hline \multirow{2}{*}{$M_{n}$ of polyol } & \multicolumn{2}{|c|}{$\mathrm{SSC} / \%^{\mathrm{a})}$} & \multicolumn{3}{|c|}{ PPG-based $T_{\mathrm{g}} /{ }^{\circ} \mathrm{C}$} & \multicolumn{3}{|c|}{ PTMG-based $T_{\mathrm{g}} /{ }^{\circ} \mathrm{C}$} \\
\hline & ITUP & PUE & PPG & ITUP & PUE & PTMG & ITUP & PUE \\
\hline 1000 & 60.4 & 76.5 & -71.1 & -32.6 & -31.2 & -80.4 & -54.0 & -53.4 \\
\hline 1500 & 73.7 & 83.2 & -70.2 & -43.8 & -44.2 & -81.0 & -61.8 & -62.8 \\
\hline 2000 & 78.6 & 86.9 & -69.8 & -49.3 & -51.5 & -82.4 & -66.7 & -66.8 \\
\hline 3000 & 84.7 & 90.9 & -69.7 & -56.2 & -58.6 & -84.0 & -71.0 & -71.4 \\
\hline
\end{tabular}

a) Calculated soft segment concentration. 
ここで， $w_{1}$ と $T_{\mathrm{g}_{1}}$ はコポリマー成分 1 の重量分率と $T_{\mathrm{g}}$ で， $w_{2}$ 々 $T_{\mathrm{g}_{2}}$ は成分 2 のそれらである. $T_{\mathrm{g}}$ は両成分により形成される 相間層 (interphase layer)の $T_{\mathrm{g}}$ であり， $T_{\mathrm{g}_{1}}$ と $T_{\mathrm{g}_{2}}$ の間に存在す る. ポリウレタンでは，この $T_{\mathrm{g}}$ は観測されず，一般にソフトセ グメント $T_{\mathrm{g}}$ 值の上昇とハードセグメント $T_{\mathrm{g}}$ 值の降下が認めら れている ${ }^{23)}$. ITUP と PUE では, 同じ $M_{\mathrm{n}}$ のポリオールを使用 すれば当然原料 MDIの重量分率に相違が生ずる(ITUP および PUEの合成ではポリオールに対する MDI のモル比は，それぞ れ 2.0, 1.0). ITUP およびPUE はともに用いるポリオールの $M_{\mathrm{n}}$ が低いほど MDI の重量分率が増大し， $T_{\mathrm{g}}$ 值が上昇する。し たがって，ソフトセグメントとハードセグメントが完全に混合し ていればITUP とPUEの $T_{\mathrm{g}}$ 值に差が認められるはずである が，上述のように顕著な相違が観測されない. ITUP と PUE は ともにソフトセグメントの両端は MDI に由来するハードセグメ ントであり, 両者の部分構造は全く同一である.このことから, ITUP および PUE の $T_{\mathrm{g}}$ 值は PPG および PTMG の鎖長に依存 することが明らかである。

PTMG 系 ITUP の DSC 曲線 (Fig. 1 の (b))では, PTMG の $M_{\mathrm{n}}$ が $1500(\mathrm{~B}), 2000(\mathrm{C}), 3000(\mathrm{D})$ の場合に $T_{\mathrm{g}}$ よりわずかに高 温側に発熱ピークが明瞭に観測される．このピークは PTMG 系 PUE の DSC 曲線 (Fig. 1 の(c))において PTMG の $M_{\mathrm{n}}$ が 1500 (B) と $2000(\mathrm{C})$ の試料にも観測される.これらの発熱ピークはソ フトセグメントの再配列結晶化に相当する. Fig. 1 の(b)，(c)では PTMG の $M_{\mathrm{n}}$ が $1500(\mathrm{~B}), 2000(\mathrm{C}), 3000(\mathrm{D})$ の場合にソフトセ グメントの融点に相当する吸熱ピーク $\left(T_{\mathrm{m}}\right)$ が観測され，この $T_{\mathrm{m}}$ 值は $M_{\mathrm{n}}$ が高くなるにつれて高温側にシフトし， $T_{\mathrm{g}}$ 值と逆の傾 向を示している。もとより, PTMG 単独の $T_{\mathrm{m}}$ も $M_{\mathrm{n}}$ 依存性が ある.PTMG の $M_{\mathrm{n}}$ が 1000, 1500, 2000, 3000 のときの $T_{\mathrm{m}}$ 值 は，それぞれ 21.4, 25.1, 26.5, $30.0{ }^{\circ} \mathrm{C}$ であり, PTMG を用いた ITUP およびPUEの融点と一致する. 一方, 融解における $\Delta H$ も PTMG の $M_{\mathrm{n}}$ 依存性が観測される. PTMGの $M_{\mathrm{n}}$ を高くする と, 融解を伴うソフトセグメントの濃度 (Table 1 参照)が高くな り, このことが $\Delta H$ の増加をもたらしている．しかしながら, $M_{\mathrm{n}}$ が 1000 のときの融解に打ける $\Delta H$ は，これより $M_{\mathrm{n}}$ が高い ITUP およびPUEのそれらよりも極端に小さい，このことは， $\Delta H$ がソフトセグメントの水素結合性と密接な関係がある証拠を 与えている.

PPG や PTMG のようなエーテル結合含有ポリオールを用いた ポリウレタンでは, ウレタン結合中の $\mathrm{NH}$ はポリオールに由来 するエーテル酸素と水素結合する. ウレタン $\mathrm{NH}$-エーテル酸素 間の水素結合は相混合度の尺度であり, Nielsen ${ }^{24)} に よ り$ 次の式 が提出されている.

$$
\frac{T_{\mathrm{gu}}-T_{\mathrm{ge}}}{T_{\mathrm{ge}}}=\frac{k X_{\mathrm{c}}}{1-X_{\mathrm{c}}}
$$

ここで, $T_{\mathrm{gu}}$ はポリウレタンのソフトセグメントのガラス転移温 度, $T_{\mathrm{ge}}$ はエーテル系ポリオールのガラス転移温度, $X_{\mathrm{c}}$ はウレ タン $\mathrm{NH}$ と水素結合したエーテル酸素のモル分率, $k$ は定数で 1.2-1.5 である. Sung ら ${ }^{25)}$ は, 式 ( 4 )にウレタン結合の水素結 合による物理的橋かけ効果を考慮した次の式を導いている.

$$
\frac{T_{\mathrm{gu}}-T_{\mathrm{ge}}}{T_{\mathrm{ge}}}=\frac{1.5 X_{\mathrm{c}}}{1-X_{\mathrm{c}}}+\frac{X_{\mathrm{c}}}{1.1+X_{\mathrm{c}}}=\frac{2.6 X_{\mathrm{c}}}{1.1-0.1 X_{\mathrm{c}}}
$$

式( 5 )に Table 1 の $T_{\mathrm{g}}$ 值を当てはめて得られた ITUP および
PUE 中の水素結合しているエーテル酸素の割合, $\mathrm{C}-\mathrm{O}-\mathrm{C}_{\mathrm{NH}}(\%)$ を Table 2(PPG 系) 拈よび Table 3(PTMG 系)に示す。これら の Table 2 抢よび 3 には, 次の式を用いてエーテル酸素と水素結 合したウレタン $\mathrm{NH}$ の割合, $\mathrm{NH}_{\mathrm{C}-\mathrm{O}-\mathrm{C}}(\%)$ も載せた.

$\mathrm{NH}_{\mathrm{C}-\mathrm{O}-\mathrm{C}}(\%)$

$=X_{\mathrm{c}} \times($ number of $\mathrm{C}-\mathrm{O}-\mathrm{C}$ unit in soft segment $) / 2(6)$

Table 2 および 3 の $\mathrm{C}-\mathrm{O}-\mathrm{C}_{\mathrm{NH}}(\%)$ はいずれも $10 \%$ 未満であ り，ほとんどの C-O-C が水素結合に関与していない，このこと は, ITUP およびPUEの水素結合による相混合度が低いことを 意味している。 また，ポリオールの $M_{\mathrm{n}}$ が高くなるにつれて $\mathrm{C}-\mathrm{O}-\mathrm{C}_{\mathrm{NH}}(\%)$ は低下し, 相混合度が低くなる. PPG 系の $\mathrm{C}-\mathrm{O}-\mathrm{C}_{\mathrm{NH}}(\%)$ と $\mathrm{PTMG}$ 系のそれを比較すると, 前者の方がわず かに高い值である.これらの結果は, ウレタン結合濃度に対する $\mathrm{C}-\mathrm{O}-\mathrm{C}$ 濃度の比は ITUP および PUE はともに 1 よりもずっと 大きく，その值はポリオールの $M_{\mathrm{n}}$ が高くなるにつれて増大する ことに帰因している. Table 2 抢よび 3 の $\mathrm{NH}_{\mathrm{C}-\mathrm{O}-\mathrm{C}}(\%)$ は,

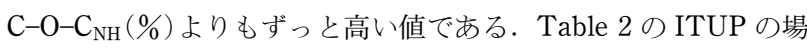
合は, $\mathrm{NH}_{\mathrm{C}-\mathrm{O}-\mathrm{C}}(\%)$ はポリオールの $M_{\mathrm{n}}$ とともにわずかに上昇す るが, PUEではほとんど変動しない.PTMG 系では, ITUP の $\mathrm{NH}_{\mathrm{C}-\mathrm{O}-\mathrm{C}}(\%)$ は PUE のそれとほぼ同じ值であるが，両者ともポ リオールの $M_{\mathrm{n}}$ とともに顕著に上昇し, これは繰り返し単位 $\mathrm{C}-\mathrm{O}$ $-\mathrm{C}$ 濃度増加に帰因している. PPG 系の $\mathrm{NH}_{\mathrm{C}-\mathrm{O}-\mathrm{C}}(\%)$ と PTMG 系のそれを比較すると, 前者の方がずっと高い值である. 一般に, PTMG のオキシテトラメチレン鎖は, Fig. 1 の(b)，(c)に再配列 結晶化の発熱ピークが室温以下で観測されるように, 配向しやす い性質を持っている.一方, PPG のオキシプロピレン鎖は側鎖 メチル基により配向が困難で非晶性の形態をとる。すなわち, PPG 系では非晶性に起因する特徵的なソフトセグメントーハード セグメント間の相互作用が大きいものと推測される.

以上の DSC により測定した $T_{\mathrm{g}}$ に基づく水素結合性に関する 考察を, 次項で実際の FTIR スペクトルによる水素結合性から

Table 2 Hydrogen bonding properties between $\mathrm{C}-\mathrm{O}-\mathrm{C}$ and

\begin{tabular}{|c|c|c|c|c|}
\hline \multirow{2}{*}{$M_{\mathrm{n}}$ of PPG } & \multicolumn{2}{|c|}{ 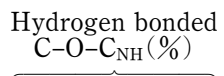 } & \multicolumn{2}{|c|}{$\begin{array}{l}\text { Hydrogen bondec } \\
\mathrm{NH}_{\mathrm{C}-\mathrm{O}-\mathrm{C}}(\%)\end{array}$} \\
\hline & ITUP & PUE & ITUP & PUE \\
\hline 1000 & 8.1 & 8.1 & 65 & 65 \\
\hline 1500 & 5.5 & 5.4 & 68 & 66 \\
\hline 2000 & 3.3 & 4.0 & 71 & 67 \\
\hline 3000 & 2.8 & 2.6 & 71 & 66 \\
\hline
\end{tabular}
NH for PPG-based ITUPs and PUEs

Table 3 Hydrogen bonding properties between $\mathrm{C}-\mathrm{O}-\mathrm{C}$ and NH for PTMG-based ITUPs and PUEs

\begin{tabular}{cccccc}
\hline \multirow{2}{*}{$M_{\mathrm{n}}$ of TMG } & \multicolumn{2}{c}{$\begin{array}{c}\text { Hydrogen bonded } \\
\text { C-O-C }\end{array}$} & & \multicolumn{2}{c}{$\begin{array}{c}\text { Hydrogen bonded } \\
\text { NH }_{\mathrm{C}-\mathrm{O}-\mathrm{C}}(\%)\end{array}$} \\
\cline { 2 - 3 } & ITUP & PUE & & ITUP & PUE \\
\hline 1000 & 5.8 & 6.0 & & 37 & 38 \\
1500 & 3.7 & 4.0 & & 42 & 39 \\
2000 & 3.1 & 3.5 & & 46 & 46 \\
3000 & 2.9 & 2.9 & 59 & 58 \\
\hline
\end{tabular}


検証する.

\subsection{FTIR}

ウレタン $\mathrm{NH}$ 伸縮振動領域およびウレタン $\mathrm{C}=\mathrm{O}$ 伸縮振動領 域の FTIR スペクトルの測定例をそれぞれ Fig. 2 抢よび 3 に示 す. Fig. 2 に抢ける $3450 \mathrm{~cm}^{-1}$ 付近の吸収は水素結合していな い遊離 $\mathrm{NH}$ 伸縮振動, $3290 \mathrm{~cm}^{-1}$ 付近の吸収は $\mathrm{NH}$ と $\mathrm{C}=\mathrm{O}$ お よび C-O-C との間の水素結合に起因する，いわゆる分子間水素 結合 $\mathrm{NH}$ 伸縮振動に帰属される ${ }^{26) 27)}$. Fig. 3 における 1735 $\mathrm{cm}^{-1}$ 付近の吸収は水素結合していない $\mathrm{C}=\mathrm{O}$ 伸縮振動, 1710 $\mathrm{cm}^{-1}$ 付近の吸収は $\mathrm{NH}$ と分子間水素結合している $\mathrm{C}=\mathrm{O}$ 伸縮 振動に帰属される26)27).

Fig. 3 のような FTIR スペクトルの波形分離により求めた ITUP および PUE のウレタン $\mathrm{C}=\mathrm{O}$ と水素結合したウレタン $\mathrm{NH}$ の割合, $\mathrm{NH}_{\mathrm{C}=\mathrm{O}}(\%)$ を Table 4 に示す. ITUP 抢よび PUE 中の $\mathrm{NH}_{\mathrm{C}=0}(\%)$ は， PPG 系および PTMG 系いずれも50\%を割 っている，それらの值はポリオールの $M_{\mathrm{n}}$ が高くなるにつれて低 下する傾向が観測される. PPG 系 ITUP およびPUE 中の $\mathrm{NH}_{\mathrm{C}=\mathrm{O}}(\%)$ と $\mathrm{PTMG}$ 系のそれらとを比較すると, 後者の方がわ ずかに高い。これはウレタン結合付近の構造の相違, すなわち PPG 系ではウレタン結合に隣接するメチル基の立体障害により ウレタンカルボニルがプロトン受容体としての機能を阻害されて いるものと推測される.

Fig. 2 のような FTIR の波形分離により求めた水素結合してい ないウレタン $\mathrm{NH}_{\text {free }}(\%), T_{\mathrm{g}}$ 值から求めた $\mathrm{NH}_{\mathrm{C}-\mathrm{O}-\mathrm{C}}(\%)$, ウレタ ン $\mathrm{C}=\mathrm{O}$ と水素結合しているウレタン $\mathrm{NH}_{\mathrm{C}=\mathrm{O}}(\%)$ を Fig. 4-7 に示す．なお，ITUP 抢よび PUE 中にはウレタン NH 以外に電 子受容性の基が存在しないことから，そして $\mathrm{C}=\mathrm{O}$ と $\mathrm{NH}$ は同 数なので $\mathrm{C}=\mathrm{O}_{\mathrm{NH}}(\%)=\mathrm{NH}_{\mathrm{C}=\mathrm{O}}(\%)$ である.

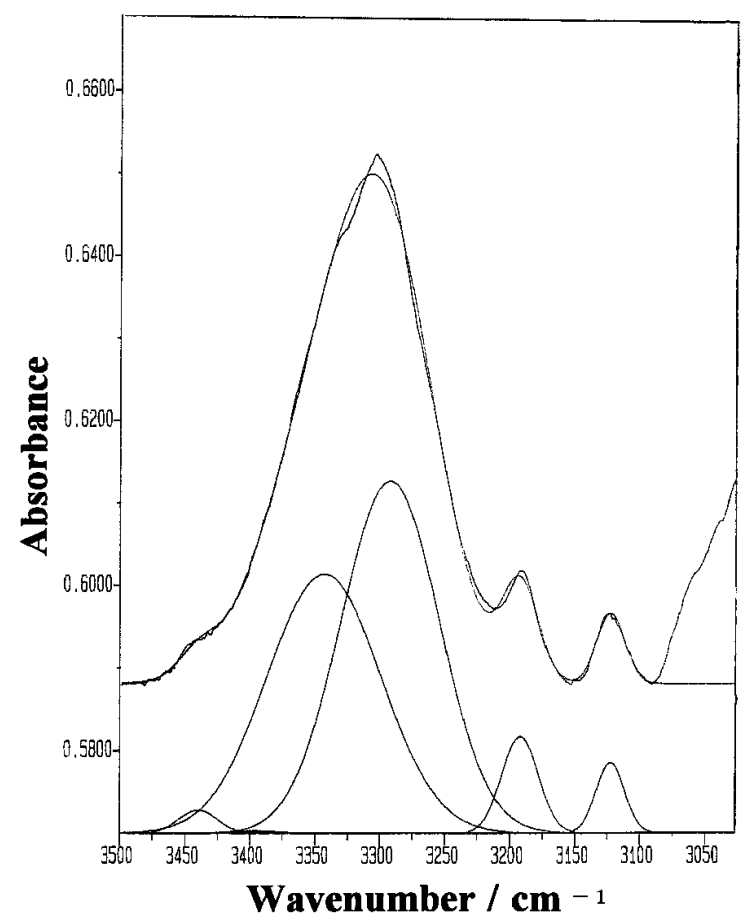

Fig. 2 FTIR spectra of $\operatorname{PPG}\left(M_{\mathrm{n}}=3000\right)$-based ITUP.
Fig. 4-7 から, PPG 系および PTMG 系の ITUP と PUE は いずれもポリオールの $M_{\mathrm{n}}$ が高くなるにつれて，ハードセグメン 卜間の水素結合である $\mathrm{NH}_{\mathrm{C}=0}(\%)$ の減少傾向が観測される. 一 方，ハードセグメントとソフトセグメント間の水素結合である $\mathrm{NH}_{\mathrm{C}-\mathrm{O}-\mathrm{C}}(\%)$ は，いずれの試料ともポリオールの $M_{\mathrm{n}}$ とともに増 加することが認められ，ソフトセグメントの鎖長に依存する.

他方，横山年 関する詳細な研究結果に基づき, ウレタン結合に対しエーテル結 合が 8 倍濃度のエーテル系ポリウレタンエラストマーでは, 水 素結合に関与しない $\mathrm{NH}$ が $15 \%, \mathrm{NH}$ と $\mathrm{C}=\mathrm{O}$ との間の水素結 合が $32 \%, \mathrm{NH}$ と C-O-C との間の水素結合が $53 \%$ と報告して いる. 著者らの Fig. 2 により求めた水素結合していないウレタ ン $\mathrm{NH}\left(\mathrm{NH}_{\text {free }}\right)$ は $1-2 \%$ であり，本実験で用いた試料すべて同様 な值であって, ウレタン $\mathrm{NH}$ はほとんど水素結合に関与してい る.

Eisenbach ら ${ }^{29)}$ は，MDI を用いたポリウレタンの固体状態に

Table 4 Hydrogen bonding properties between $\mathrm{NH}$ and $\mathrm{C}=\mathrm{O}$ for ITUPs and PUEs

\begin{tabular}{|c|c|c|c|c|}
\hline \multirow[t]{2}{*}{$M_{\mathrm{n}}$ of polyol } & \multicolumn{2}{|c|}{$\begin{array}{c}\text { Hydrogen bonded } \\
>\mathrm{NH}_{\mathrm{C}=\mathrm{O}}(\%) \\
\text { for } \mathrm{PPG} \text { system }\end{array}$} & \multicolumn{2}{|c|}{$\begin{array}{l}\text { Hydrogen bonded } \\
>\mathrm{NH}_{\mathrm{C}}=\mathrm{O}(\%) \\
\text { for PTMG system }\end{array}$} \\
\hline & ITUP & PUE & ITUP & PUE \\
\hline 1000 & 36 & 35 & 40 & 47 \\
\hline 1500 & 26 & 24 & 34 & 39 \\
\hline 2000 & 26 & 23 & 32 & 32 \\
\hline 3000 & 25 & 17 & 22 & 30 \\
\hline
\end{tabular}

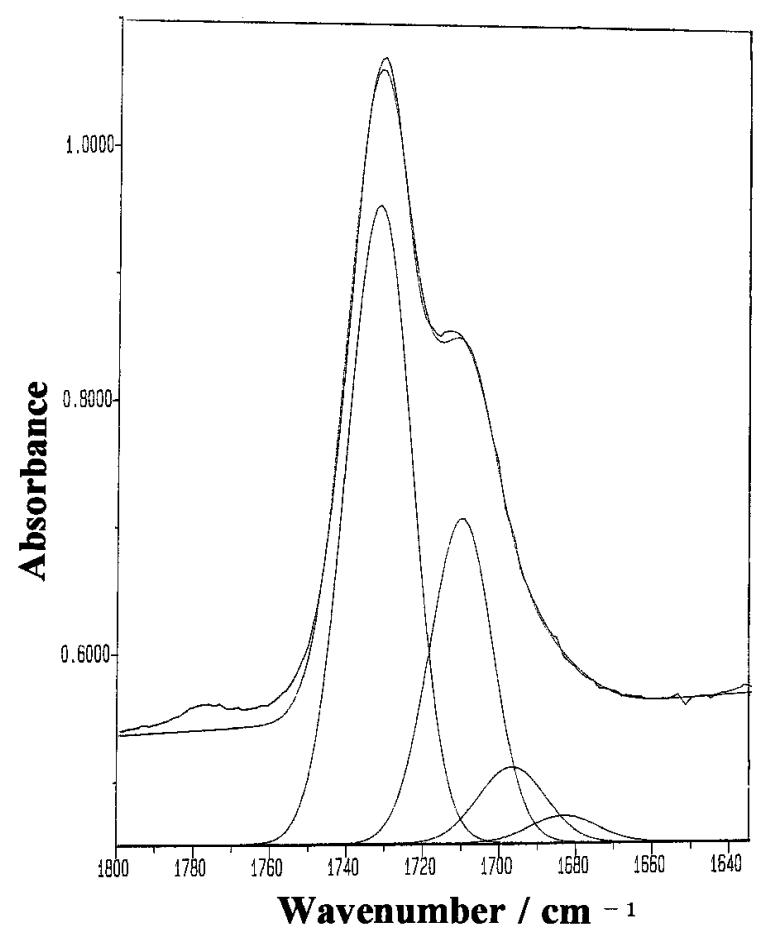

Fig. 3 FTIR spectra of PTMG $\left(M_{\mathrm{n}}=1000\right)$-based ITUP. 


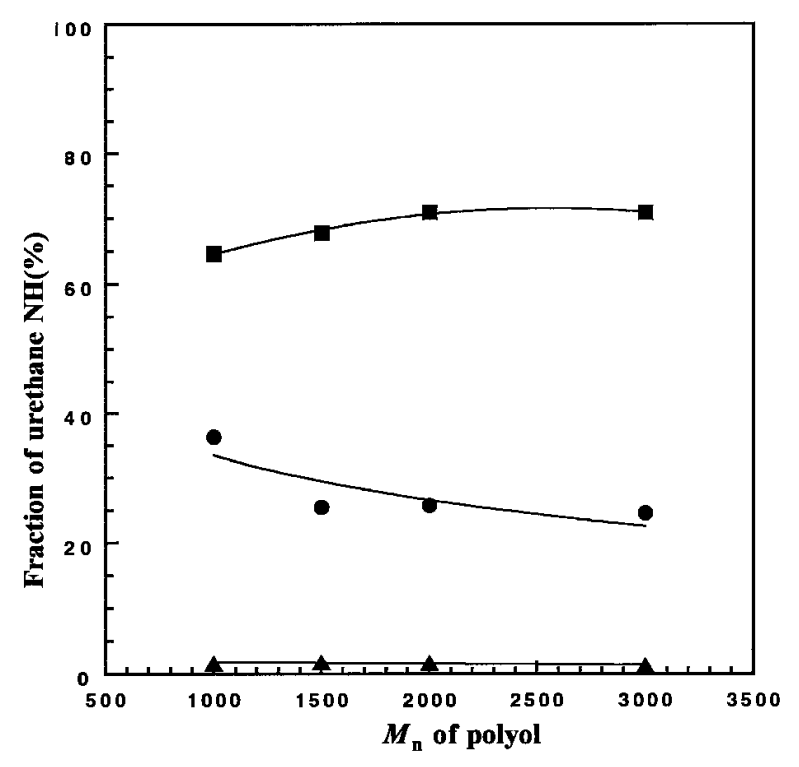

Fig. 4 Hydrogen bonding properties of urethane $\mathrm{NH}$ in PPG-based ITUP.

$\boldsymbol{\Delta}: \mathrm{NH}_{\text {free }}, \mathbf{O}: \mathrm{NH}_{\mathrm{C}=\mathrm{O}}, \boldsymbol{\square}: \mathrm{NH}_{\mathrm{C}-\mathrm{O}-\mathrm{C}}$.

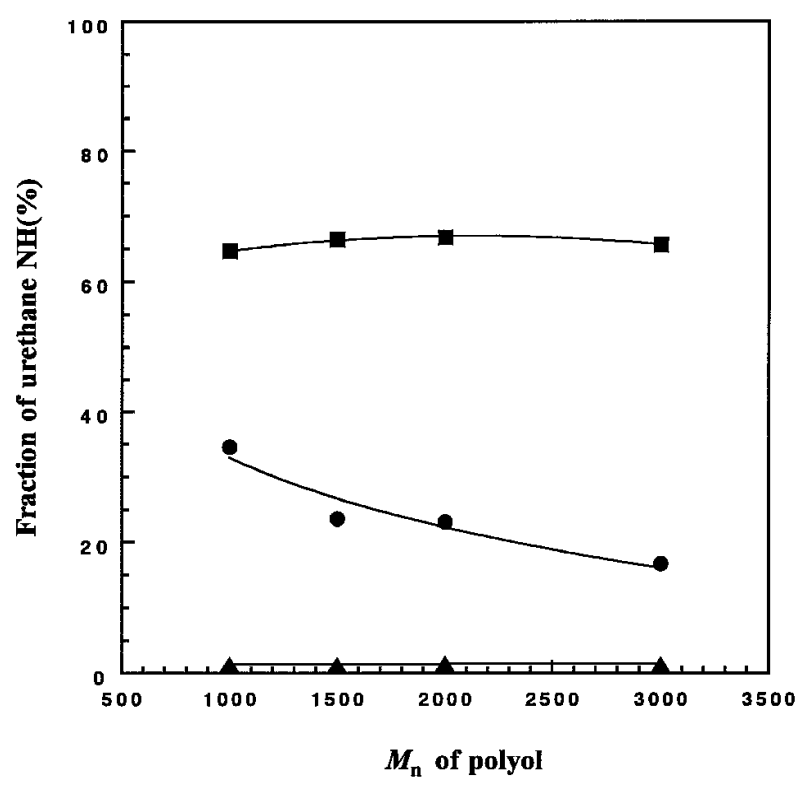

Fig. 5 Hydrogen bonding properties of urethane $\mathrm{NH}$ in PPG-based PUE.

$\mathbf{\Delta}: \mathrm{NH}_{\text {free }}, \mathbf{O}: \mathrm{NH}_{\mathrm{C}=\mathrm{O}}, \boldsymbol{\square}: \mathrm{NH}_{\mathrm{C}-\mathrm{O}-\mathrm{C}}$.

おける水素結合に関する研究を ${ }^{13} \mathrm{C}-\mathrm{NMR} に よ り$ 行い, ウレタン $\mathrm{NH}$ に隣接するべンゼン環炭素のシグナルが単一であることか ら, ウレタン $\mathrm{NH}$ はすべて水素結合していると推定している. また $\mathrm{Lu}$ ら $^{30)}$ は, MDI を用いたポリウレタンの $\mathrm{DMF}-d_{7}$ 中での ${ }^{1} \mathrm{H}-\mathrm{NMR}$ 研究から, 水素結合に関与しないウレタン $\mathrm{NH}$ は存在 しないことを報告している.

ウレタン結合の水素結合性に関しては，これまで述べてきたウ レタン $\mathrm{NH}$ とウレタンカルボニルとの水素結合, ウレタン $\mathrm{NH}$

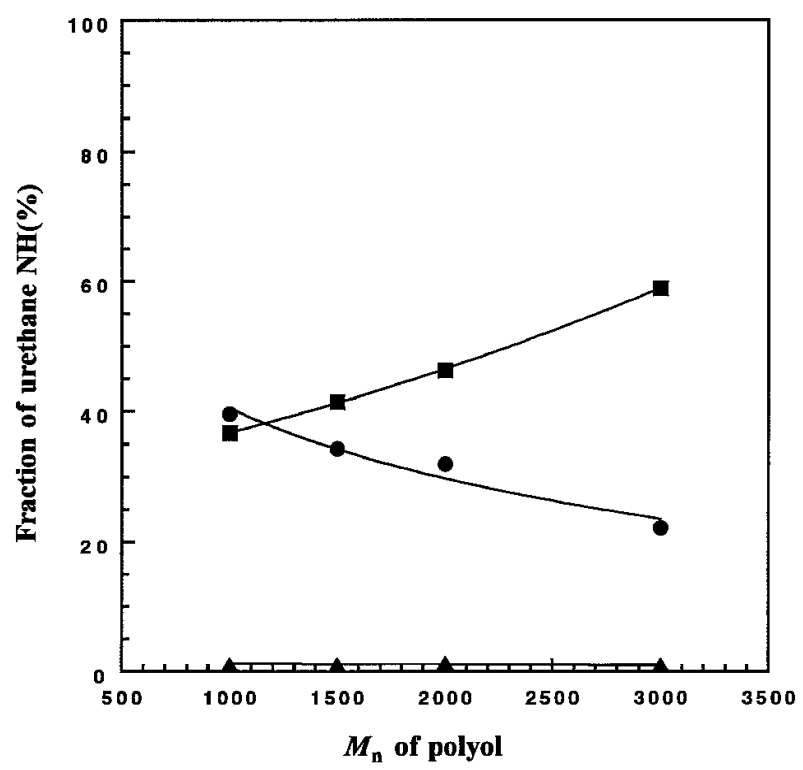

Fig. 6 Hydrogen bonding properties of urethane $\mathrm{NH}$ in PTMG-based ITUP.

$\boldsymbol{\Delta}: \mathrm{NH}_{\text {free }}, \mathbf{O} \mathrm{NH}_{\mathrm{C}=\mathrm{O}}, \mathbf{\square}: \mathrm{NH}_{\mathrm{C}-\mathrm{O}-\mathrm{C}}$.

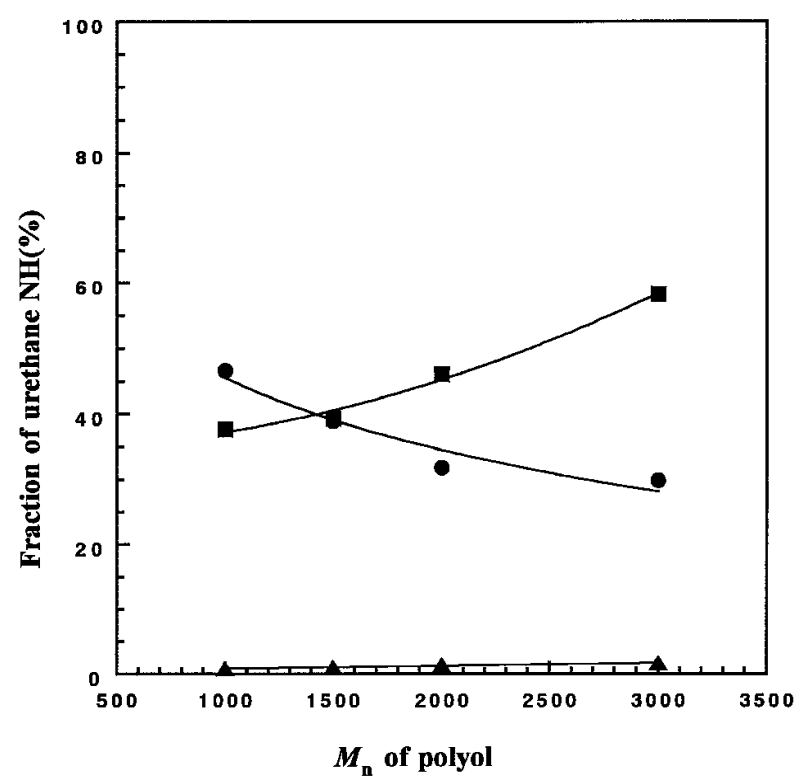

Fig. 7 Hydrogen bonding properties of urethane $\mathrm{NH}$ in PTMG-based PUE.

$\boldsymbol{\Delta}: \mathrm{NH}_{\text {free }}, \mathbf{O}: \mathrm{NH}_{\mathrm{C}=\mathrm{O}}, \boldsymbol{\square}: \mathrm{NH}_{\mathrm{C}-\mathrm{O}-\mathrm{C}}$.

とポリオールのエーテル酸素との水素結合のほかにウレタン $\mathrm{NH}$ とウレタンのアルコキシ酸素との水素結合が知られている. エ一 テル結合を含まない 1,4-ブタンジオールのような低分子ジオー ルと MDI とのポリウレタンではアルコキシ酸素とウレタン NH との水素結合が観測されている31)。さらにエーテル結合を含む ポリウレタン中でもアルコキシ酸素とウレタン $\mathrm{NH}$ との水素結 合の存在が推測されている25)。このことは，Fig. 2 に抢ける $3290 \mathrm{~cm}^{-1}$ 付近の吸收帯にはウレタン $\mathrm{NH}$ とエーテル酸素との 
水素結合のほかにウレタン $\mathrm{NH}$ とアルコキシ酸素との間の水素 結合に起因するピークが包含されている可能性があるが，現在の ところこれらを分離することは困難である.

\section{4 結 論}

$\mathrm{MDI} / \mathrm{PPG}$ または PTMG 系ウレタンプレポリマーおよびポリ ウレタンエラストマーのガラス転移温度抢よび水素結合性をそれ ぞれ DSC およびFT-IR により調べた結果, 以下の結論を得た.

(1) ITUP および PUE の $T_{\mathrm{g}}$ 值はポリオールの $M_{\mathrm{n}}$ とともに 低下するが，両者の $T_{\mathrm{g}}$ 值に有意差は認められない.

(2) PPG 系 ITUP および PUE の $T_{\mathrm{g}}$ 值と PTMG 系 ITUP お よび PUEの $T_{\mathrm{g}}$ 值を，それぞれポリオール単独の $T_{\mathrm{g}}$ 值と比較す ると, 結晶性の PTMG 系よりも非晶性の PPG 系の方が大幅に 上昇する.

（3） ITUP および PUE 中の水素結合による物理的橋かけがソ フトセグメントとハードセグメントとの間およびハードセグメン トとハードセグメントとの間に形成され，後者の方が橋かけ密度 は高い.

(4) $\mathrm{PPG}$ 系の $\mathrm{NH}_{\mathrm{C}-\mathrm{O}-\mathrm{C}}(\%)$ は PTMG 系のそれよりも高く, 逆 に $\mathrm{PPG}$ 系の $\mathrm{NH}_{\mathrm{C}=0}(\%)$ はTMG 系のそれよりも低いことから, PTMG 系の方が強固なハードドメインが形成される.

1) Z. S. Petrović, J. B. Simendic, Rubber Chem. Technol., 58, 685(1985).

2) C. P. Christenson, M. A. Harthcock, M. D. Meadows, H. L. Spell, W. L. Howard, M. W. Creswick, R. E. Guerra, R. B. Turner, J. Polym. Sci., Part B: Polym. Phys., 24, 1401 (1986).

3) Z. S. Petrović, J. Polym. Sci., Part B: Polym. Phys., 27, 545 (1989).

4) B. Nabeth, I. Corniglion, J. P. Pascault, J. Polym. Sci., Part B: Polym. Phys., 34, 401(1996).

5) T. K. Chen, T. S. Shieh, J. Y. Chui, Macromolecules, 31, 1312(1998).

6) 松永勝治, 大塚知明, 志村朋美, 日化, 1998, 849 .

7) C. H. Y. C. Tsai, E. L. Thomas, W. J. MacKnight, N. S.
Schneider, Polymer, 27, 659(1986).

8）松永勝治, 川村将一, 林 直樹, 日化, 1996, 667.

9) F. Prochazka, T. Nicolai, D. Durand, Macromolecules, 29, 2260 (1996).

10) P. Cassagnau, F. Melis, A. Michel, J. Appl. Polym. Sci., 65, 2395 (1997).

11) Z. S. Petrović, F. Coco, L. Horvath, N. Dulic, J. Appl. Polym. Sci., 38, 1929(1989).

12) V. V. Zharkov, A. G. Strikovsky, T. E. Verteletskaya, Polymer, 34, 938(1993).

13) N. Reynolds, H. W. Spiess, H. Nefzger, C. D. Eisenbach, Macromol. Chem. Phys., 195, 2855 (1994).

14) W. Tang, W. J. MacKnight, S. L. Hsu, Macromolecules, 28, 4284(1995).

15) M. J. Elwell, A. J. Ryan, H. J. M. Grunbauer, H. C. V. Lieshout, Polymer, 37, 1353(1996).

16) L. S. Teo, C. Y. Chen, J. F. Kuo, Macromolecules, 30, 1793 (1997).

17) F. S. Yen, L. L. Lin, J. L. Hong, Macromolecules, 32, 3068 (1999).

18) R. A. Assink, J. Polym. Sci., Polym. Phys. Ed., 15, 59 (1977).

19) X. Lu, Y. Wang, X. Wu, Polymer, 35, 2315(1994).

20) G. Yang, Q. Chen, Y. Wang, C. Yang, X. Wu, J. Molecul. Struct., 323, 209(1994).

21）松永勝治, 遠山光雄, 菅原栄一, 近江 誠, 日化, 1996, 311.

22) P. R. Couchman, Macromolecules, 11, 1156(1978).

23) Z. S. Petrović, J. Ferguson, Prog. Polym. Sci., 16, 695 (1991).

24) L. E. Nielsen, J. Macromol. Chem., Rev. Macromol. Chem., 3, 69 (1969).

25) P. Sung, N. S. Schneider, Macromolecules, 8, 68(1975).

26) R. W. Seymour, G. M. Estes, S. L. Cooper, Macromolecules, 3, 579(1970).

27) M. M. Coleman, D. J. Skrovanek, J. Hu, P. C. Painter, Macromolecules, 21, 59(1988).

28) T. Yokoyama, Adv. Urethane Sci. Technol., 6, 1(1978).

29) C. D. Eisebbach, W. Gronski, Makromol. Chem., Rapid Commun. 4, 707(1983).

30) X. Lu, M. Hou, X. Gao, S. Chen, Polymer, 35, 2510 (1994).

31) J. Bandekar, S. Klima, J. Mol. Struct., 263, 45(1991). 


\title{
Hydrogen Bonding Properties of Ether-Based Urethane Prepolymers and Polyurethane Elastomers
}

\author{
Katsuji Matsunaga*, Makoto Oumi ${ }^{\dagger}$, Masahiro Tajima and Yasuhiko Yoshida \\ Department of Applied Chemistry, Faculty of Engineering, Toyo University; 2100 Kujirai, \\ Kawagoe-shi 350-8585 Japan \\ ${ }^{\dagger}$ Present address: Asahi Denka Kogyo Co. Ltd. Functional Polymer R\&D Laboratory; 20, \\ Syowanuma, Syobu-cho, Minamisaitama-gun, Saitama 346-0101 Japan
}

Isocyanate-terminated urethane prepolymers(ITUP) and polyurethane elastomers(PUE) have been prepared by the reaction of 4,4'-methylenebis (phenyl) diisocyanate with polyether diols such as $\alpha-$ hydro- $\omega$-hydroxypoly (oxypropylene) (PPG) or $\alpha$-hydro- $\omega$-hydroxypoly (oxytetramethylene) (PTMG) of various molecular weights. Characterization of the ITUP and the PUE has been carried out by means of differential scanning calorimetry and FTIR spectroscopy. In this article, discussion is made with the interaction development between soft and hard segments on the basis of the evaluated glass-transition temperatures $\left(T_{\mathrm{g}}\right)$ and the hydrogen bond interaction among the urethane- and the ether-linkages in molecular chain. The $T_{\mathrm{g}}$ values of ITUP and PUE are considerably high in comparison with those of only the PPG and the PTMG. This implies that the micro-Brownian motion of the oxypropylene and the oxytetramethylene moiety is restricted by the hard segment which contains the urethane linkages having a high activity of the hydrogen bond interaction. Physical crosslinks by the hydrogen bond in the ITUP and PUE are formed between the soft segment and the hard segment and between the hard segment and the hard segment, and the degree of crosslinking is higher with the latter. The PPG-based $\mathrm{NH}_{\mathrm{C}-\mathrm{O}-\mathrm{C}}(\%)$ is higher than the PTMG-based one, whereas the PPG-based $\mathrm{NH}_{\mathrm{C}=\mathrm{O}}(\%)$ is lower than the PTMG-based one. Thus rigid hard domain is formed rather with the PTMG-based one. 